\title{
Politik Hukum Pembaruan Undang-Undang Nomor 9 Tahun 1961 Tentang Pengumpulan Uang Atau Barang Dalam Kegiatan Filantropi Di Indonesia
}

\author{
Rr. Dyah Citra Harina \\ Program Magister Ilmu Hukum Pascasarjana FH UII \\ Jln. Cik Di Tiro No. 1 Yogyakarta 55223 \\ dyahcitra.harina@ rocketmail.com
}

\begin{abstract}
Philanthropy based on Law No. 9 of 1961 on Collection of Money or Goods. But as the times evolve, Law No. 9 of 1961 is considered as a weak legal basis for the implementation of philanthropy in Indonesia. Whilst on the other hand, the funds collected through philanthropic activities have the potentials to support the achievement of Sustainable Development Goals. Therefore, the focus of this study discusses: 1) How the legal policy of reforming Law No. 9 of 1961 on Collection of Money or Goods in philanthropic activities in Indonesia; 2) How is the renewal of Law No. 9 of 1961 in philanthropic activities in Indonesia to support the achievement of SDGs 2030. This is a normative study and analyzed using descriptive analysis. This research concludes that the reform of Law No. 9 of 1961 can not be separated from other elements outside the law that have a role in the occurrence of changes in society. Legal certainty is emphasized in order to achieve justice. In addition, the responsiveness of the lawmakers is also needed in order to update Law No. 9 of 1961 can support the achievement of TPB nationally.
\end{abstract}

Keyword: Law reform; philanthropy; SDGs

\begin{abstract}
Abstrak
Filantropi berlandaskan UU No. 9 Tahun 1961 tentang Pengumpulan Uang atau Barang. Namun seiring berkembangnya jaman, UU No. 9 Tahun 1961 dinilai sudah tidak bisa menjadi dasar hukum yang kuat bagi pelaksanaan filantropi di Indonesia. Padahal di sisi lain, dana yang terkumpul melalui kegiatan filantropi memiliki potensi untuk mendukung tercapainya Sustainable Development Goals. Oleh karena itu, fokus penelitin ini membahas: 1) Bagaimana politik hukum pembaruan Undang-undang No. 9 Tahun 1961 tentang Pengumpulan Uang atau Barang dalam kegiatan filantropi di Indonesia; 2) Bagaimana pembaruan Undang-undang No. 9 Tahun 1961 dalam kegiatan filantropi di Indonesia sebagai penunjang pencapaian SDGs 2030. Penelitian ini merupakan penelitian normatif dan dianalisis dengan menggunakan analisa deskriptif. Penelitian ini menyimpulkan bahwa pembaruan Undang-undang No. 9 Tahun 1961 tidak bisa dipisahkan dari unsur-unsur lain di luar hukum yang memiliki andil dalam terjadinya perubahan di masyarakat. Kepastian hukum dititik beratkan agar dapat mencapai keadilan. Selain itu, responsifitas pembuat hukum juga diperlukan agar pembaruan Undang-undang No. 9 Tahun 1961 dapat mendukung tercapainya TPB secara nasional..
\end{abstract}

Kata-kata Kunci: Pembaruan undang-undang; filantropi; SDGs 


\section{Pendahuluan}

Perubahan tradisi, kebiasaan dan norma yang terjadi di masyarakat memiliki efek samping, yaitu munculnya masalah yang harus diselesaikan. Mayoritas merupakan masalah dalam isu kesejahteraan dan tuntutan agar masyarakat juga berperan aktif dalam upaya penyelesaian masalah-masalah tersebut. Salah satu hal yang dapat menjadi solusi untuk mengatasai masalah-masalah tersebut adalah dengan kegiatan kemanusiaan yang dalam dunia akademik disebut dengan istilah filantropi. Istilah filantropi dalam definisi secara umum berasal dari kata philanthropia atau dalam bahasa Yunani philo dan anthropos yang berarti cinta manusia. Filantropi merupakan bentuk kepedulian seseorang atau sekelompok orang terhadap orang lain berdasarkan kecintaan pada sesama manusia.

Filantropi dapat berarti cinta kasih (kedermawanan) kepada sesama. Secara lebih luas, akar kata filantropi adalah "loving people" sehingga banyak dipraktikkan oleh entitas budaya dan komunitas keberagamaan di belahan dunia, sehingga aktivitas filantropi sudah lama berjalan. ${ }^{1}$ Filantropi merupakan salah satu pendekatan dari tiga pendekatan untuk mempromosikan kesejahteraan termasuk di dalamnya upaya pengentasan kemiskinan yaitu pendekatan social service (social administration), social work dan philanthropy. Filantropi sebagai salah satu modal sosial telah menyatu di dalam kultur komunal (tradisi) yang telah mengakar sejak lama, khususnya di masyarakat pedesaan.

Fakta kultural menunjukkan bahwa tradisi filantropi dilestarikan melalui pemberian derma kepada teman, keluarga, dan tetangga yang kurang beruntung. Ciri lainnya ditunjukkan dengan tuntutan masyarakat untuk memprioritaskan tujuan meringankan beban orang miskin. ${ }^{2}$ Namun filantropi bukan merupakan aksi individu, melainkan aksi yang lebih kompleks lagi, bisa dalam bentuk aksi kelompok bahkan juga aksi yang dilakukan oleh korporasi. ${ }^{3}$

${ }^{1}$ Makhrus Ahmadi, "Pengembangan Dana Zakat, Infak, Shadaqah dan Wakaf terhadap Pertumbuhan Industri Keuangan Non Bank Syariah”, Jurnal Masharif al-Syariah, Edisi No. 2 Vol. 2, 2017, hlm. 3.

2 Pirac, Investing in Our Selves ;Giving and Fund Raising In Indonesia, Dikutip dari Imron Hadi Tamim, "Peran Filantropi dalam Pengentasan Kemiskinan di dalam Komunitas Lokal”, Jurnal Sosiologi Islam, Edisi No. 1 Vol. 1 , April, 2011, hlm.36.

3 Imron Hadi Tamim, "Filantropi dan Pembangunan", Community Development, Edisi No. 1 Vol. 1, Juni, 2016, hlm. 122. 
Dasar hukum berjalannya filantropi di Indonesia selama ini berdasarkan Undang-Undang No. 9 Tahun 1961 tentang Pengumpulan Uang atau Barang.4 Namun seiring semakin berkembangnya zaman, UU No. 9 Tahun 1961 dinilai sudah tidak bisa menjadi dasar hukum yang kuat bagi pelaksanaan filantropi di Indonesia. Misalnya dalam perihal perijinan, UU No. 9 Tahun 1961 mengatur proses perizinan harus dilakukan 3 bulan sekali, padahal jangka waktu yang termasuk sempit ini cukup merepotkan bagi lembaga sosial untuk memperbarui izinnya. Selain itu, sumbangan juga dikotak-kotakkan dalam regional, lokal dan nasional, padahal jika menggunakan media sosial tidak mungkin dibatasi cakupan wilayahnya. Masalah lain berhubungan dengan sanksi dari dilakukannya pelanggaran yang hanya didenda Rp10.000,005 Selain masalah yang disebutkan sebelumnya, salah satu masalah yang cukup krusial adalah sumber dana dan pengelolaan dana lembaga filantropi yang masih abu-abu hingga kini sehingga menimbulkan keraguan bahwa sumbangan benar-benar sampai tepat sasaran.

Hambatan lain juga datang dari masyarakat sendiri. Mayoritas masyarakat masih asing dengan istilah filantropi, kegiatan penggalangan dana kedermawanan marak dilakukan hanya pada saat adanya momentum, misalnya ketika terdapat peristiwa kebencanaan. Selain itu, masalah juga timbul dari praktik filantropi yang melibatkan tayangan televisi yang terjadi pada 2013. Harry Tanoe melalui tayangan berita Seputar Indonesia Pagi (RCTI) mengumumkan bahwa dana HT Foundation merupakan dananya pribadi, tetapi dalam pemberitaan di saluran televisi lain (Global TV dan MNC TV) mengatakan bahwa masyarakat memiliki andi dalam dana sumbangan tersebut.

Pengakuan atas potensi kegiatan filantropi di Indonesia sebagai salah satu unsur penting bagi pembangunan yang berkelanjutan di Indonesia dapat dilihat pada Perpres No. 59 Tahun 2017 tentang Pelaksanaan Pencapaian Tujuan Pembangunan Berkelanjutan. Salah satu elemen yang dilibatkan dalam pelaksanaan pencapaian Sustainable Develpoment Goals (SDGs) adalah filantropi.

\footnotetext{
${ }^{4}$ Undang-undang ini berlaku untuk filantropi umum, bukan filantropi Islam yang merupakan kewenangan Kemenag dan memiliki UU yang berbeda.

${ }^{5}$ http://majalahcsr.id/ruu-pub-untuk-kepercayaan-pada-lembaga-filantropi/, Akses pada 28 Mei 2018.
} 
Pasal 3 huruf (b) Perpres No. 59 Tahun 2017 berisi bahwa Perpres tersebut merupakan acuan bagi Ormas, Filantropi, Pelaku Usaha, Akademisi dan pemangku kepentingan lainnya yang akan menyusun perencanaan, pelaksanaan dan pemantauan serta evaluasi Tujuan Pembangunan Berkelanjutan (TPB).

Potensi yang dimiliki oleh filantropi diperlukan agar dapat menjadi salah satu solusi dari masalah-masalah yang dialami oleh Indonesia. Filantropi diharapkan dapat mendukung upaya mengatasi kemiskinan, kesejahteraan, kesehatan dan pendidikan sehingga tujuan-tujuan yang telah dirumuskan dalam program pembangunan berkelanjutan dapat tercapai. Legitimasi filantropi di Indonesia sudah diakui melalui Perpres No. 59 Tahun 2017, tapi pengaturan yang bersifat khusus mengenai lembaga filantropi dan kegiatan filantropi itu sendiri justru masih kabur karena dasar hukum yang telah ada dan digunakan sebelumnya, yaitu berdasarkan UU No. 9 Tahun 1961 sudah tidak dapat mengakomodasi perkembangan filantropi. Persoalan ini menimbulkan ketidakpastian hukum. Oleh karena itu diperlukan pembaruan hukum terkait aturan yang menjadi dasar hukum dari filantropi, baik dari sisi kegiatannya maupun kelembagaannya.

\section{Rumusan Masalah}

Adapun rumusan masalah dalam penelitian ini terdapat dua poin, yaitu: pertama, bagaimana politik hukum pembaruan Undang-Undang No. 9 Tahun 1961 tentang Pengumpulan Uang atau Barang dalam Kegiatan Filantropi di Indonesia? Kedua, bagaimana pengaruh pembaruan Undang-Undang No. 9 Tahun 1961 dalam kegiatan filantropi di Indonesia terhadap upaya pencapaian SDGs 2030?

\section{Tujuan Penelitian}

Berdasarkan uraian latar belakang yang telah disebutkan sebelumnya, maka tujuan yang hendak dicapai penelitian ini adalah: pertama, untuk menganalisis perlunya pembaruan hukum yang menjadi dasar dari berjalannya filantropi di Indonesia. Kedua, untuk mengetahui dampak dari pembaruan hukum tentang filantropi di Indonesia terhadap optimalisasi pencapaian SDGs 2030. 


\section{Metode Penelitian}

Penelitian ini merupakan penelitian normatif, yaitu penelitian terhadap asasasas dan kaidah-kaidah hukum, peraturan perundang-undangan, pendapat ahli, yurisprudensi. ${ }^{6}$ Bahan hukum yang digunakan antara lain Undang-Undang No. 9 Tahun 1961 tentang Pengumpulan Uang atau Barang, Undang-Undang No. 32 Tahun 2002 tentang Penyiaran, Peraturan Pemerintah No. 29 Tahun 1980 tentang Pelaksanaan Pengumpulan Sumbangan, Peraturan Pemerintah No. 22 Tahun 2008 tentang Pendanaan dan Pengelolaan Bantuan Bencana, Peraturan Presiden No. 59 Tahun 2017 tentang Pelaksanaan Pencapaian Tujuan Pembangunan Berkelanjutan, Peraturan Komisi Penyiaran Indonesia Nomor 01/P/KPI/03/2012 tentang Pedoman Perilaku Penyiaran. Bahan-bahan hukum yang telah dikelompokkan dan diklasifikasikan selanjutnya dianalisis secara deskriptif.7

\section{Hasil Penelitian dan Pembahasan}

\section{Politik Hukum Pembaruan Undang-Undang Nomor 9 Tahun 1961 tentang} Pengumpulan Uang atau Barang dalam Kegiatan Filantropi di Indonesia

Pasal 34 UUD 1945 yang berisi mengenai kesejahteraan sosial sejalan dengan Tujuan Pembangunan Berkelanjutan (TPB - yang bisa disebut juga dengan Sustainable Development Goals). Pasal 3 huruf (b) Peraturan Presiden No. 59 Tahun 2017 tentang Pelaksanaan Pencapaian Tujuan Pembangungan Berkelanjutan menentukan bahwa sebagai acuan bagi Ormas, Filantropi, Pelaku Usaha, Akademisi dan pemangku kepentingan lainnya yang akan menyusun perencanaan, pelaksanaan dan pemantauan serta evaluasi TPB..$^{8}$ Berdasarkan pasal tersebut, salah satu pihak yang berkepentingan dalam pelaksanaan TPB atau dapat disebut juga dengan SDGs adalah filantropi. Yang dimaksud dengan filantropi berdasarkan Pasal 1 ayat (9) Peraturan Presiden No. 59 Tahun 2017 adalah pihak yang berbagi dukungan dan sumber daya secara sukarela kepada sesama dan bertujuan untuk mengatasi

${ }^{6}$ Singgih Widagdo, "Analisis Yuridis terhadap Undang-undang No. 4 Tahun 2009 tentang Pertambangan Mineral dan Batubara dari Aspek Hukum Bisnis”, Tesis, Program Magister Hukum, Universitas Gadjah Mada, Yogyakarta, 2011, hlm. 60.

${ }^{7}$ Ibid.

8 Pasal 3 huruf (b) Peraturan Presiden No. 59 Tahun 2017 tentang Pelaksanaan Pencapaian Tujuan Pembangungan Berkelanjutan. 
masalah sosial kemanusiaan serta memajukan kepentingan umum dan berkelanjutan. ${ }^{9}$

Filantropi selama ini berjalan berlandaskan Undang-Undang No. 9 Tahun 1961 tentang Pengumpulan Uang atau Barang. Pasal 1 UU No. 9 Tahun 1961 menentukan bahwa Yang diartikan dengan pengumpulan uang atau barang dalam undang-undang ini adalah setiap usaha mendapatkan uang atau barang untuk pembangunan dalam bidang kesejahteraan sosial, mental/agama/kerohanian, kejasmanian dan bidang kebudayaan.10 Beradasarkan pengertian tersebut, maka definisi umum mengenai kegiatan filantropi sejalan dengan Pasal 1 UU No. 9 Tahun 1961. Namun setelah ditelaah lebih lanjut, isi UU No. 9 Tahun 1961 sudah tidak bisa menjadi dasar hukum yang mumpuni bagi kegiatan filantropi di masa kini. Hal ini disebabkan karena perkembangan filantropi, khususnya setelah masa reformasi, berjalan sangat pesat sedangkan dasar hukum yang digunakan masih dasar hukum lama. Kegiatan filantropi tidak hanya berjalan dengan cara penerimaan dan pemberian donasi/sumbangan secara manual, namun juga telah memanfaatkan teknologi informasi seperti internet, sedangkan pada UU No.9 Tahun 1961 belum mengatur mengenai kegiatan filantropi yang lebih kompleks.

Hukum yang berjalan di Indonesia merupakan hukum "warisan" bangsa Eropa, maka dari itu sistem hukum yang berjalan di Indonesia termasuk dalam sistem hukum sipil (civil law) yang bersifat positivistik. ${ }^{11}$ Ciri positivisme adalah obyektif atau bebas nilai. Oleh karena itu, menurut Donny Gahral Adian, di dalam paradigma positivisme ada dikotomi yang tegas antara fakta dan nilai, mengharuskan subyek peneliti mengambil jarak terhadap realitas dengan sikap netral.12 Tidak dapat dipungkiri bahwa kriteria bebas nilai yang menjadi bagian dari ciri paradigma positivisme justru membuat tidak mampu melihat sesuatu yang salah pada suatu tatanan masyarakat. ${ }^{13}$ Selain itu, pengaruh paradigma

\footnotetext{
9 Pasal 1 ayat (9) Peraturan Presiden No. 59 Tahun 2017 tentang Pelaksanaan Pencapaian Tujuan Pembangungan Berkelanjutan.

${ }_{10}$ Pasal 1 Undang-Undang No. 9 Tahun 1961 tentang Pengumpulan Uang atau Barang.

11 Choky R. Ramadhan, "Konvergensi Civil Law dan Common Law di Indonesia dalam Penemuan dan Pembentukan Hukum”, Mimbar Hukum, No. 2 Vol. 30, Juni 2018, hlm. 214.

12 Donny Gahral Adian, Arus Pemikiran Kontemporer: Atheisme, Positivisme Logis, Neo Marxisme, Dikutip dari FX Adji Samekto, Studi Hukum Kritis: Kritik Terhadap Hukum Modern, PT Citra Aditya Bakti, Bandung, 2005, hlm. 33.

13 Ibid., hlm. 41.
} 
positivisme yang melahirkan school of jurisprudence yang disebut dengan formalisme meyakini bahwa dalam menangani suatu kasus, hakim akan mengidentifikasi prinsip dan aturan yang relevan, dan akan menerapkannya secara deduktif tanpa bantuan pendekatan dari perspektif lain (taat terhadap undang-undang). ${ }^{14}$ Karena kekakuan dari sistem civil law yang positivistik tersebut, hukum gagap untuk tanggap pada perubahan yang terjadi di masyarakat.

Salah satu kritik terhadap positivisme hukum terdapat dalam teori hukum kritis. Studi hukum kritis atau yang biasa dikenal dengan Critical Legal Studies (CLS) hadir sebagai penentang norma-norma dan standar-standar di dalam teori dan praktik hukum yang selama ini telah diterima. CLS menentang tradisi positivistik yang melakukan penyelesaian hukum dengan cara deduktif dari aturan-aturan yang sudah ada terhadap masalah yang belum ada. Keputusan-keputusan dihasilkan dari penerapan prinsip-prinsip, preseden-preseden dan prosedurprosedur tanpa mengacu konteks politik, sosial dan ekonomi, tujuan-tujuan sosial dan nilai-nilai. CLS percaya bahwa logika-logika dan struktur hukum muncul dari adanya power relationship dalam masyarakat. Hukum tidak dapat dipisahkan dari politik, ${ }^{15}$ maka dari itu hukum menjadi tidak netral dan bebas nilai. ${ }^{16}$

Bekerjanya hukum di masyarakat membutuhkan suatu perantara yang memungkinkan hukum melakukan regenerasi dan penerapan norma-norma. Hal tersebut hanya dapat dilakukan apabila manusia yang menjadi perantaranya. Kompleksitas yang terjadi di masyarakat modern melahirkan stratifikasi yang juga menjadi pembeda antara masyarakat yang berada dalam suatu strata dengan masyarakat yang berada dalam strata lain dalam hal memaknai hukum. Semakin tinggi kedudukan suatu kelompok secara ekonomi maupun politik, semakin besar pula kemungkinannya bahwa pandangan serta kepentingannya akan tercermin di dalam hukum.

${ }^{14}$ Ibid., hlm 71.

15 Pengertian hukum tidak dapat dipisahkan dengan negara dalam arti luas (masyarakat bernegara). Berbicara tentang negara, otomatis berbicara mengenai organisasi kekuasaan sehingga hukum memiliki hubungan erat dengan kekuasaan. Di lain sisi, politik selalu bersinggungan dengan kekuasaan. Maka dari itu, hukum dan politik selalu bersinggungan. - Darji Darmodiharjo, Pokok-pokok. Filsafat Hukum: Apa dan Bagaimana Filsafat Hukum Indonesia, PT Gramedia Pustaka Utama, Jakarta, 1995, hlm. 188.

${ }^{16}$ FX Adji Samekto, Studi Hukum Kritis..., Op. Cit., hlm. 57-58. 
Hukum tidak netral dan tidak bebas nilai, hal ini dibuktikan bahwa politik memiliki peran penting dalam hukum, baik pada saat pembuatannya maupun proses pemberlakuannya, karena terdapat tarik menarik kepentingan masyarakat yang berada dalam strata yang berbeda. Pengaruh faktor sosial dan personal yang terdapat dalam masing-masing peran yang dilakukan, baik itu dalam masyarakat, lembaga legislatif maupun lembaga penegak hukum dalam sejalan dengan yang diklaim oleh CLS. Individu-individu pembuat keputusan baik yang berperan sebagai masyarakat biasa, lembaga legislatif maupun lembaga penegak hukum merupakan subyek kehendak utama dalam tatanan sosial. Keyakinannya dalam membuat suatu keputusan ditentukan oleh lingkungan politik, sosial dan ekonomi. Hukum bukan seperti yang dikatakan oleh teori-teori positivis yang mengatakan bahwa hukum memiliki sifat tertutup. Hukum sangat dipengaruhi oleh ideologi, politik, ekonomi, sosial dan budaya. Suatu logika yang terbuka bahwa perkembangan kebutuhan masyarakat sangat memengaruhi pertumbuhan hukum di dalam masyarakat. ${ }^{17}$

Pasal 28D ayat (1) UUD 1945 menentukan bahwa Setiap orang berhak atas pengakuan, jaminan, perlindungan dan kepastian hukum yang adil serta perlakuan yang sama di hadapan hukum. ${ }^{18}$ Kepastian hukum menuntut aturan yang termuat dalam produk hukum diberlakukan secara sama kepada semua warga negara. Hukum sebagai tolok ukur obyektif dalam menyelesaikan konflik sosial di dalam dirinya sendiri harus bersifat obyektif. Sedangkan adil menurut hukum diartikan sebagai apa yang secara tegas diharuskan oleh pembentuk undang-undang. Undangundang itu sendiri dibuat dengan tujuan kebaikan, keamanan, perdamaian dan terwujudnya keadilan bagi seluruh masyarakat. Pembuat undang-undang harus merumuskan substansi dari undang-undang tersebut sesuai dengan standar moral dan kebahagiaan umum sehingga rakyat bersedia menerima dan menaatinya yang di dalamnya tercakup seluruh hakikat dan daya keadilan. ${ }^{19}$

${ }^{17}$ Marsudi Dedi Putra, "Kontribusi Aliran Sociological Jurisprudence Terhadap Pembangunan Sistem Hukum Indonesia”, Likhitaprajna, Edisi No. 2 Vol. 16, 2014, hlm. 51.

18 Pasal 28D ayat (1) Undang-Uundang Dasar Negara Republik Indonesia Tahun 1945.

19 Abdul Manan, Peranan Hukum dalam Pembangunan Ekonomi, Cetakan Pertama, Prenadamedia Group, Jakarta, 2014, hlm. 63. 
Aturan hukum hendaknya bersifat netral terhadap kepentingan perorangan maupun golongan, tetapi harus berpihak pada rasa keadilan di masyarakat. Hukum bertugas melindungi warganya agar tidak mendapatkan perlakuan diskriminatif. Aturan hukum agar lebih menjamin aspek kepastiannya maka perlu dirumuskan produk peraturan perundang-undangan. Aturan hukum harus jelas dan konsisten agar tidak membingungkan warganya. Hukum yang tidak pasti tentunya tidak memiliki kekuatan berlaku secara mengikat, dan ini merupakan sesuatu yang buruk. ${ }^{20}$

Agar pembaruan hukum dapat mengikat dan memiliki kekuatan hukum yang pasti sehingga ketertiban dalam masyarakat dapat tercapai, maka perlu adanya kepastian hukum. Pembaruan hukum dilakukan dengan mengatur mengenai kegiatan filantropi di Indonesia dan/atau penyelenggaraan sumbangan masyarakat. Kepastian hukum juga dapat menanggulangi salah satu kelemahan CLS, yaitu terjebaknya CLS pada nihilisme karena hanya berkutat pada kritik di ranah wacana sehingga melupakan fungsi praktis hukum bagi masyarakat. Kepastian hukum dalam konteks ini bukan bermakna bahwa hukum harus tertutup dan tidak memungkinkan untuk diubah. Kepastian hukum dalam hal ini diartikan sebagai kejelasan norma, sehingga dapat dijadikan pedoman masyarakat yang dikenakan peraturan ini. Kepastian hukum dimaknai sebagai kejelasan dan ketegasan terhadap berlakunya hukum di masyarakat. Hal ini agar tidak menimbulkan banyak salah tafsir. Karena adanya kejelasan hukum yang berlaku sama kepada seluruh masyarakat, maka keadilan dapat dicapai.

Kesadaran hukum masyarakat akan timbul apabila ada kesesuaian antara keadilan yang hidup di dalam masyarakat dengan keadilan yang ingin dicapai oleh hukum yang sedang berlaku. Kepastian hukum sebaiknya harus selalu ditegakkan karena di dalam kepastian hukum terkandung nilai keadilan hukum. Antara kepastian dan keadilan merupakan dua sisi yang tidak dapat dipisahkan karena keduanya saling mengisi. Dari hal ini maka akan tercipta hukum positif yang dapat

${ }^{20}$ B. Wibowo Suliantoro, "Dinamika Arah Kepastian Hukum di Tengah Transformasi Sosial-Budaya dalam Perspektif Pemikiran Mazhab Sociological Jurisprudence”, Jurnal Filsafat, Edisi No. 1 Vol. 17, 2007, hlm. 20. 
mengayomi kehidupan masyarakat dan secara tidak langsung akan tercipta hukum yang berdimensi keadilan dan kebenaran. ${ }^{21}$

Pembaruan Undang-Undang No. 9 Tahun 1961 tentang Pengumpulan Uang atau Barang dalam Kegiatan Filantropi di Indonesia sebagai Penunjang Pencapaian SDGs 2030

Semua masyarakat yang sedang membangun selalu dicirikan dengan adanya perubahan dan pembangunan. Proses pembangunan membawa konsekuensi terjadinya perubahan di beberapa aspek sosial, termasuk pranata hukum. Perubahan yang dilakukan dalam perjalanannya menuntut adanya perubahanperubahan dalam bentuk hukum. Perubahan tersebut memiliki arti positif dalam rangka menciptakan sistem hukum baru yang sesuai dengan kondisi nilai-nilai yang ada di masyarakat. Hukum diakui memiliki peran yang sangat penting dan strategis dalam memacu percepatan pembangunan suatu negara. Usaha ini tidak hanya dalam rangka memenuhi tuntutan pembangunan jangka pendek, tetapi juga jangka menengah serta jangka panjang meskipun dapat disadari juga bahwa hukum dapat berubah sesuai dengan kebutuhan masyarakat.22

Perubahan Undang-Undang No. 9 Tahun 1961 dalam rangka pembaruan dasar hukum filantropi di Indonesia sesungguhnya untuk menyesuaikan dengan kondisi terkini masyarakat dalam hubungannya dengan kegiatan filantropi. Pembaruan dasar hukum filantropi diharapkan dapat menjadi dasar hukum yang lebih adil bagi stakeholders yang terkait dengan filantropi. Hal ini dikarenakan mencangkup hak dan kewajiban pihak-pihak terkait serta ketentuan-ketentuan lain yang lebih akomodatif terhadap kegiatan filantropi di masa kini. Undang-undang No. 9 Tahun 1961 sudah tidak sesuai dengan perkembangan kegiatan filantropi. Beberapa ketentuan dalam UU No. 9 Tahun 1961 harus diubah, diperbarui, maupun ditambah agar sesuai dengan tujuan pembangunan Indonesia.

\section{Pengumpulan Dana Sumbangan Berbasis Internet/Teknologi Informasi}

Pasal 5 ayat (2) UU No. 9 Tahun 1961 menentukan syarat permohonan izin penyelenggaraan pengumpulan uang atau barang yang harus mencangkup 6 hal,

\footnotetext{
21 Abdul Manan, Peranan Hukum dalam..., Op. Cit., hlm. 65.

${ }^{22}$ Marsudi Dedi Putra, "Kontribusi Aliran Sociological..., Op. Cit., hlm. 54-55.
} 
yaitu a) Maksud dan tujuan pengumpulan uang atau barang; b) Cara menyelenggarakan; c) Siapa yang menyelenggarakan; d) Batas waktu penyelenggaraan; e) Luasnya penyelenggaraan (wilayah, golongan); f) Cara penyalurannya. ${ }^{23}$ Meski dalam Pasal 5 ayat (2) huruf b berisi mengenai cara penyelenggaraan pengumpulan uang atau barang, namun hal ini belum cukup rinci mengenai ketentuan penyelenggaraan. PP No. 29 Tahun 1980 sebagai peraturan pelaksanannya juga belum mengatur hal tersebut. Salah satunya adalah penyelenggaraan pengumpulan sumbangan dengan memakai jaringan internet. Padahal kegiatan filantropi saat ini marak dilakukan dengan memanfaatkan media sosial dan jaringan internet.

Diperlukan pengaturan mengenai pengumpulan dana sumbangan yang berbasis tekonologi, atau yang dikenal dengan istilah crowdfunding. Crowdfunding adalah suatu model pendanaan yang melibatkan beberapa aktor, yaitu pemilik proyek, lembaga crowdfunding/crowdsourcing yang biasanya merupakan situs online atau media sosial dan donatur. ${ }^{24}$ Crowdfunding diyakini mampu mendanai berbagai aktivitas yang sulit dilakukan oleh akses pendanaan konvensional seperti bank dan investor yang prosesnya memerlukan berbagai persyaratan dan melalui birokrasi yang panjang. Kelebihan dari crowdfunding adalah proses pengaksesan dananya sangat mudah.

Penggalang dana hanya mempublikasikan aktivitasnya yang butuh didanai dalam bentuk proposal secara daring (online) dengan mencantumkan jumlah dana yang dibutuhkan. Untuk mempermudah, biasanya pemohon dana mempublikasikannya melalui pihak ketiga, yaitu penyedia layanan atau crowdsourcing. Beberapa pemohon dana dapat mempublikasikannya secara mandiri (melalui akun media sosial miliknya). Crowd (donatur potensial/penyandang dana) yang mengakses laman website dengan konten proposal tersebut jika tertarik untuk mendanai akan menyumbangkan atau meminjamkan dananya sesuai dengan

\footnotetext{
${ }^{23}$ Pasal 5 ayat (2) UU No. 9 Tahun 1961 tentang Pengumpulan Uang atau Barang.

${ }_{24}$ Maulana Irfan, "Crowdfunding Sebagai Pemaknaan Energi Gotong Royong Terbarukan”, Social Work Jurnal, Edisi No. 1 Vol. 6, 2016, hlm. 9.
} 
klausul proposal daring yang telah dipublikasikan. ${ }^{25}$ Di Indonesia, terdapat beberapa laman yang terkenal sebagai penggalang donasi melalui internet yaitu Kitabisa (kitabisa.com), Gandengtangan (gandengtangan.org), Wujudkan (wujudkan.com), AyoPeduli (ayopeduli.com) dan Crowdtivate (crowdtivate.com).

Hingga kini belum ada dasar hukum yang mengatur mengenai penggalangan donasi berdasarkan crowdfunding sehingga riskan terjadi kasus. Salah satu kasus Cak Budi yang kerap menggalang dana bantuan sosial. Akun Instagram @cakbudi_ dikenal sebagai akun yang sering menggalang dana bantuan sosial. Berdasarkan pengakuannya, terdapat donasi yang terkumpul senilai Rp 1.200.000.000,00 (Rp. $560.000 .000,00$ donasi ke rekening pribadi, Rp. 700.000 .000 donasi ke laman Kitabisa) yang belum disalurkan. Dia mengakui bahwa telah menggunakan uang donasi untuk pembelian iPhone 7 yang menurutnya digunakan untuk mengambil foto dan video para penerima hak dan lokasi yang dikunjungi. Selain itu dia juga membeli mobil Fortuner untuk menempuh jarak jauh dan menjangkau area-area pedalaman. ${ }^{26}$ Kasus tersebut menggambarkan bahwa karena belum adanya pengaturan yang jelas mengenai crowdfunding, dana bantuan masyarakat yang terkumpul bisa disalahgunakan untuk kepentingan yang tidak berkaitan langsung terhadap sasaran dana sosial.

\section{Pengelolaan Dana Sumbangan untuk Keperluan Operasionalisasi Kegiatan Pengumpulan Dana}

Hal penting kedua yang harus diatur dengan lebih terperinci adalah mengenai alokasi dana yang dapat digunakan untuk biaya operasional selama kegiatan penyelenggaraan pengumpulan sumbangan berlangsung. UU No. 9 Tahun 1961 belum mengatur hal tersebut, tetapi diatur dalam Pasal 6 ayat (1) PP No. 29 Tahun 1980 yang berisi Pembiayaan usaha pengumpulan sumbangan sebanyakbanyaknya $10 \%$ (sepuluh persen) dari hasil pengumpulan sumbangan yang bersangkutan. ${ }^{27}$ Namun dari alokasi $10 \%$ yang dapat digunakan untuk pembiayaan operasional kegiatan pengumpulan sumbangan belum ada pengaturan secara rinci

25 Gita Widi Bhawika, "Risiko Dehumanisasi pada Crowdfunding sebagai Akses Pendanaan Berbasis Teknologi di Indonesia”, Jurnal Sosio Humaniora, Edisi No. 1 Vol. 10, Juni 2017, hlm. 47.

26 https://www.antaranews.com/berita/627182/cak-budi-dan-fenomena-penggalangan-donasi-online, Akses pada 2 Februari 2019.

${ }^{27}$ Pasal 6 ayat (1) PP No. 29 Tahun 1980 tentang Pelaksanaan Pengumpulan Sumbangan. 
mengenai dana yang dapat digunakan pada masing-masing pos. Misalnya, untuk kebutuhan konsumsi, transportasi dan keperluan lain yang sekiranya diperlukan. Pasal 9 PP No. 22 Tahun 2008 tentang Pendanaan dan Pengelolaan Bantuan Bencana berisi bahwa: 28

1) Setiap pengumpulan dana penanggulangan bencana, wajib mendapat izin dari instansi/lembaga yang berwenang.

2) Setiap izin yang diberikan oleh instansi/lembaga sebagaimana dimaksud pada ayat (1) salinannya disampaikan kepada BNPB atau BPBD.

3) Tata cara perizinan pengumpulan dana penanggulangan bencana dilakukan sesuai dengan ketentuan peraturan perundang-undangan.

Pasal 9 ayat (1) sampai dengan ayat (3) di atas tidak menyebutkan berapa persen dana yang didapat dari sumbangan masyarakat yang bisa digunakan sebagai operasionalisasi. Padahal biaya operasional sumbangan yang ditujukan untuk keperluan bantuan bencana alam tentu akan berbeda dengan sumbangan yang ditujukan untuk non bencana alam.

\section{Pemisahan Rekening Dana Sumbangan}

Belum diatur baik dalam UU No. 9 Tahun 1961 maupun PP No. 29 Tahun 1980 mengenai pengelolaan dana hasil sumbangan, salah satunya dengan cara memisah rekening yang digunakan khusus untuk pengumpulan dana sumbangan sehingga dana sumbangan tidak akan bercampur dengan dana pribadi. Hal ini juga berkaitan dengan aspek transparansi yang masih sangat lemah dalam pengelolaan dana filantropi karena akan sangat riskan tercampur apabila tidak ada pemisahan antara rekening khusus sumbangan dengan rekening pribadi.

\section{Pengaturan Penerimaan Donasi Melalui Media Elektronik}

Melalui tayangan berita Seputar Indonesia Pagi (RCTI), Harry Tanoe mengumumkan bahwa dana HT Foundation adalah dananya pribadi yang berbeda dengan program MNC TV Peduli, RCTI Peduli, dan Global TV Peduli. Tetapi logo program filantropi ketiga perusahaan televisi tersebut pernah muncul dalam satu pemberitaan di RCTI yang kemudian hilang dalam pemberitaan selanjutnya.

28 Pasal 9 PP No. 22 Tahun 2008 tentang Pendanaan dan Pengelolaan Bantuan Bencana. 
Seharusnya dana yang terkumpul melalui HT Foundation bukanlah dana pribadi, melainkan juga berasal dari dana masyarakat. Pasal 69 ayat (2) Peraturan Komisi Penyiaran Indonesia Nomor 01/P/KPI/03/2012 tentang Pedoman Perilaku Penyiaran mengatur Dana yang dikumpulkan dari khalayak harus dinyatakan sebagai sumbangan masyarakat. ${ }^{29} \mathrm{Hal}$ ini berarti program pengumpulan sumbangan yang dilakukan melalui RCTI telah menyimpang, namun dalam UU No. 9 Tahun 1961 belum diatur mengenai mekanisme sehingga menimbulkan kebingungan karena tidak ada kejelasan hukum mengenai hal tersebut.

\section{Mekanisme Pelaporan Penyelenggaraan dan Hasil Sumbangan}

Belum adanya ketentuan mengenai mekanisme pelaporan penyelenggaraan dan hasil sumbangan baik dalam UU No. 9 Tahun 1961 maupun PP No. 29 Tahun 1980. Karena tidak adanya ketentuan mengenai pelaporan, maka transparansi dari kegiatan pengumpulan sumbangan tidak akan tercapai sehingga dana yang terkumpul riskan digunakan untuk keperluan yang tidak ada kaitannya dengan kegiatan pengumpulan sumbangan. Kasus yang marak di media sosial Twitter mengenai dana sumbangan adalah ada satu pihak (dapat disebut dengan A) yang membuka donasi untuk keperluan membantu pengobatan anak B, setelah dana banyak terkumpul dan donasi ditutup, A akan menyerahkan hasil sumbangan kepada anak B. Namun setelah dikonfirmasi kepada pihak keluarga B, A hanya menyerahkan sebagian dari jumlah total sumbangan. Pihak donatur menuntut untuk diberikan laporan rincian penggunaan dana, namun A tidak memberikan.

\section{Pembedaan Dana Filantropi dengan Dana CSR}

Pasal 69 ayat (3) Peraturan Komisi Penyiaran Indonesia Nomor 01/P/KPI/03/2012 tentang Pedoman Perilaku Penyiaran berisi bahwa Sumbangan masyarakat sebagaimana yang dimaksud pada ayat (2) di atas tidak dapat digunakan dalam kegiatan tanggung jawab sosial lembaga penyiaran (Corporate Social Responsibility/CSR) sebagai pengumpul dan pengelola dana sumbangan.30 Terkait dengan hal tersebut, berdasarkan penelitian yang dilakukan oleh PIRAC (Public Interest Research and

${ }^{29}$ Pasal 69 ayat (2) Peraturan Komisi Penyiaran Indonesia Nomor 01/P/KPI/03/2012 tentang Pedoman Perilaku Penyiaran.

30 Pasal 69 ayat (3) Peraturan Komisi Penyiaran Indonesia Nomor 01/P/KPI/03/2012 tentang Pedoman Perilaku Penyiaran. 
Advocacy Center) dalam tahap penyaluran dana sumbangan terdapat masalah, yaitu a) Tidak adanya pemisahan yang tegas antara kegiatan sosial yang menggunakan dana sumbangan publik dengan kegiatan CSR; b) bantuan yang digalang publik diklaim dan dimanfaatkan untuk kegiatan CSR perusahaan media. ${ }^{31}$ Maka dari itu perlu aturan dan pengawasan tegas mengenai pembedaan antara dana yang berasal dari sumbangan publik dengan dana CSR pada tahap penyaluran dana sumbangan. Selain itu, juga diperlukan kejelasan apakah dana CSR diperbolehkan untuk kegiatan filantropi atau tidak.

\section{Bentuk Badan Usaha}

UU No. 9 Tahun 1961 dan PP No. 29 Tahun 1980 belum mengatur mengenai bentuk badan usaha atau organisasi yang diperbolehkan untuk melakukan kegiatan pengumpulan sumbangan secara berlanjut. Pasal 3 ayat (1) PP No. 29 Tahun 1980 berisi bahwa Usaha pengumpulan sumbangan dilakukan oleh organisasi dan berdasarkan sukarela tanpa paksaan langsung atau tidak langsung.32 Sedangkan yang dimaksud dengan organisasi merujuk pada Pasal 1 angka 2 PP No. 29 Tahun 1980, Organisasi adalah organisasi kemasyarakatan Indonesia yang memenuhi persyaratan tertentu yang mempunyai program, upaya dan kegiatan yang ditujukan untuk mewujudkan, membina, memelihara dan meningkatkan kesejahteraan sosial masyarakat. ${ }^{33}$

Organisasi yang dimaksud dalam PP No. 29 Tahun 1980 hanya disebut sebagai organisasi kemasyarakatan. Merujuk Pasal 10 ayat (1) UU No. 17 Tahun 2013 tentang Organisasi Kemasyarakatan menyatakan bahwa Ormas dapat berbentuk: a) Badan hukum atau b) Tidak berbadan hukum. Pasal 11 ayat (1) menyatakan bahwa Ormas berbadan hukum sebagaimana dimaksud dalam Pasal 10 ayat (1) huruf a dapat berbentuk: a) Perkumpulan atau b) Yayasan. Ormas berbadan hukum dinyatakan terdaftar setelah mendapatkan pengesahan status badan hukum. Setelah memeroleh status tersebut, ormas tersebut tidak memerlukan surat keterangan hlm. 29.

${ }^{31}$ Draft Naskah Akademik Rancangan Undang-undang tentang Penyelenggaraan Sumbangan..., Op. Cit.,

32 Pasal 3 ayat (1) PP No. 29 Tahun 1980 tentang Pelaksanaan Pengumpulan Sumbangan.

33 Pasal 1 angka 2 PP No. 29 Tahun 1980 tentang Pelaksanaan Pengumpulan Sumbangan. 
terdaftar seperti yang dibutuhkan oleh ormas yang tidak berbadan hukum. ${ }^{34}$ Ormas berbadan hukum perkumpulan berbasis anggota, sedangkan ormas berbadan hukum yayasan tidak berbasis anggota. ${ }^{35}$

Filantropi di Indonesia yang merupakan lembaga nirlaba mandiri merupakan wadah berkumpul dan berjejaring para filantropis Indonesia. Keanggotaan Filantropi Indonesia terbuka untuk yayasan, ${ }^{36}$ dan institusi lain yang memberikan perhatian pada kegiatan filantropi di Indonesia. ${ }^{37}$ Terkait dengan bentuk badan usaha, dalam UU yang baru sudah selayaknya terdapat kejelasan mengenai bentuk badan usaha yang dapat menjadi pihak yang menggalang dana. Hal ini sebagai langkah antisipasi untuk mengurangi munculnya kasus-kasus yang timbul akibat dari pihak penggalang dana yang tidak kredibel dan tidak bertanggung jawab. Selain itu, penentuan bentuk badan usaha dari lembaga filantropi juga terkait dengan keperluan untuk pemisahan rekening (membuat rekening baru) yang khusus digunakan untuk keperluan penampungan dana sumbangan/donasi.

\section{Penerapan Sanksi}

Pasal 8 ayat (1) UU No. 9 Tahun 1961 mengatur ketentuan pidana terhadap pelanggar kegiatan filantropi. Dipidana dengan pidana kurungan selama-lamanya 3 (tiga) bulan atau dengan setinggi-tingginya $R p$ 10.000,- (sepuluh ribu rupiah), barang siapa: (a) menyelenggarakan, menganjurkan atau membantu menyelenggarakan pengumpulan uang atau barang dengan tidak mendapat izin lebih dahulu seperti dimaksud dalam pasal 1 ayat 1; (b) tidak memenuhi syarat-syarat dan perintah yang tercantum dalam keputusan pemberian izin; (c) tidak mentaati ketentuan-ketentuan dalam Pasal 7.38 Penerapan sanksi tersebut tidak dapat memberikan efek jera para pelanggar karena terlalu ringan. Besaran denda yang diterapkan juga terlalu sedikit pada masa kini.

\footnotetext{
34 Pasal 15 ayat (3) dan Pasal 16 ayat (1) UU No. 17 Tahun 2013 tentang Organisasi Kemasyarakatan, dikutip dari Iswi Hariyani dan Cita Yustisia Serfiyani, "Perlindungan Hukum Sistem Donation Based Crowdfunding pada Pendanaan Industri Kreatif di Indonesia”, Jurnal Legislasi Indonesia, Edisi No. 4 Vol. 12, Desember 2015, hlm. 356.

35 Pasal 11 ayat (2) dan (3) UU No. 17 Tahun 2013 tentang Organisasi Kemasyarakatan dikutip dari Ibid.

36 Dapat berbentuk yayasan/perhimpunan amal dan sosial, yayasan perusahaan atau yayasan karyawan perusahaan, yayasan keluarga, yayasan/perhimpunan komunitas, yayasan/perhimpunan berbasis keagamaan.

37 http:/ / filantropi.or.id/keanggotaan, Akses pada 3 Februari 2019.

38 Pasal 8 ayat (1) UU No. 9 Tahun 1961 tentang Pengumpulan Uang atau Barang.
} 


\section{Pengaturan Penggalangan Dana Sumbangan Melalui Retail Modern}

Toko retail modern mulai marak menggalang dana sumbangan masyarakat melalui kasir. Biasanya kasir akan menanyakan pada saat pelanggan membayar “Rp. 50,00 nya boleh didonasikan kak?". Jumlah yang didonasikan tidak pasti, tergantung dengan total belanjaan pelanggan. Hal ini agar total belanja pelanggan menjadi genap. Misalnya total belanja pelanggan A adalah Rp. 14.950,00, maka kasir akan menanyakan Rp. 50,00 boleh didonasikan atau tidak agar total belanja pelanggan menjadi genap Rp. 15.000,00. Lain dengan pelanggan B yang total belanjanya Rp. 19.025,00, maka kasir akan menanyakan Rp. 75,00 boleh didonasikan atau tidak agar total belanja genap menjadi Rp. 20.000,00.

Jika satu orang di satu toko retail di satu lokasi menyumbang setidaknya Rp. 50,00, maka jika dikali dengan jumlah orang yang datang dan berkenan menyumbang di toko tersebut dikali lagi dengan 30 hari dikali dengan jumlah toko retail di satu kota, jumlahnya tidak bisa dibilang sedikit. Masyarakat yang turut menyumbang memiliki hak untuk tahu mengenai hasil sumbangan tersebut. Namun hal tersebut belum diatur baik dalam UU No. 9 Tahun 1961 maupun dalam PP No. 29 Tahun 1980. Pembangunan yang dilakukan oleh suatu negara merupakan keniscayaan dan keharusan, sebab dengan adanya pembangunan tersebut kesejahteraan rakyat dapat dicapai.

Undang-Undang No. 17 Tahun 2007 tentang Rencana Pembangunan Jangka Panjang Nasional 2005-2025 menjelaskan bahwa pembangunan nasional adalah rangkaian upaya pembangunan yang berkesinambungan yang meliputi aspek kehidupan masyarakat, bangsa dan negara untuk melaksanakan tugas mewujudkan tujuan nasional sebagaimana dirumuskan dalam pembukaan UUD 1945. Oleh karena pembangunan yang sedang dan akan dilaksanakan di Indonesia mencangkup jangkauan yang sangat luas, maka diperlukan hukum untuk memayungi seluruh kegiatan pembangunan yang sedang dan akan dilaksanakan. Agar pembangunan dapat terlaksana sebagaimana yang diharapkan, maka peranan hukum sebagai alat pembangunan tersebut sangat diperlukan, baik pada 
tahap perencanaan, pelaksanaan, maupun ketika dilakukan pengendalian dan pengawasan pembangunan tersebut. ${ }^{39}$

RPJP Nasional 2005-2025 menjelaskan bahwa dalam pembangunan hukum di Indonesia diarahkan kepada hal-hal sebagai berikut: 40

a. Pembangunan hukum diarahkan pada makin terwujudnya sistem hukum nasional yang mantap bersumber pada Pancasila dan UUD 1945, yang mencangkup pembangunan materi hukum, struktur hukum termasuk aparat hukum, sarana dan prasarana hukum, perwujudan masyarakat yang memiliki kesadaran dan budaya hukum yang tinggi dalam rangka mewujudkan negara hukum serta penciptaan kehidupan masyarakat yang adil dan demokratis.

b. Pembangunan materi hukum diarahkan untuk melanjutkan pembaruan produk hukum untuk menggantikan peraturan peraturan perundangundangan warisan kolonial yang mencerminkan nilai-nilai sosial dan kepentingan masyarakat Indonesia serta mampu mendorong tumbuhnya kreativitas dan melibatkan masyarakat untuk mendukung pelaksanaan penyelenggaraan pemerintahan dan pembangunan nasional yang bersumber pada Pancasila dan UUD 1945 yang mencangkup perencanaan hukum, pembentukan hukum, penelitian dan pengembangan hukum.

c. Pembangunan struktur hukum diarahkan untuk memantapkan dan mengefektifkan berbagai organisasi dan lembaga hukum, profesi hukum dan badan peradilan sehingga aparatur hukum mampu melaksanakan tugas dan kewajibannya secara profesional.

d. Penerapan dan penegakan hukum dan HAM dilaksanakan secara tegas, lugas, profesional dan tidak diskriminatif dengan tetap berdasarkan pada penghormatan terhadap HAM, keadilan dan kebenaran, terutama dalam penyelidikan, penyidikan dan persidangan yang transparan dan terbuka dalam rangka mewujudkan tertib sosial sehingga dapat mendukung pembangunan serta memantapkan stabilitas nasional yang mantap dan dinamis.

e. Peningkatan perwujudan masyarakat yang memiliki kesadaran hukum yang tinggi terus ditingkatkan dengan lebih memberikan akses terhadap segala informasi yang dibutuhkan masyarakat dan akses kepada masyarakat terhadap pelibatan dalam berbagai proses pengambilan keputusan pelaksanaan pembangunan nasional sehingga setiap anggota masyarakat menyadari dan menghayati hak dan kewajibannya sebagai warga negara.

f. Penuntasan penanggulangan penyalahgunaan kewenangan aparatur negara dicapai dengan penerapan prinsip-prinsip tata pemerintahan yang baik pada semua tingkatan lini pemerintahan dan semua kegiatan; pemberian sanksi seberat-beratnya kepada pelaku penyalahgunaan

\footnotetext{
39 Abdul Manan, Peranan Hukum dalam..., Op. Cit., hlm. 56-58.

${ }^{40}$ Ibid., hlm. 37-41.
} 
kewenangan sesuai dengan ketentuan yang berlaku; peningkatan intensitas dan efektivitas pengawasan aparatur negara melalui pengawasan internal, pengawasan fungsional dan pengawasan masyarakat; serta peningkatan etika birokrasi dan budaya kerja serta pengetahuan dan pemahaman para penyelenggara negara terhadap prinsip-prinsip tata pemerintahan yang baik.

Peran negara sangat krusial dalam memastikan bahwa pelaksanaan SDGs mendasarkan pada pendekatan dan strategi yang holistik antara pembangunan ekonomi, inklusi sosial dan keberlanjutan lingkungan dengan tetap mengedepankan pada karakteristik dan prioritas tiap-tiap negara. ${ }^{41}$ Prioritas pembangunan nasional jangka menengah Indonesia telah didokumentasikan dalam Rencana Pembangunan Jangka Menengah Nasional (RPJMN). RPJMN 20152019 merupakan tahap ketiga dari pelaksanaan RPJPN 2005-2025 yang ditetapkan melalui Perpres No. 2 Tahun 2015.42

Meskipun RPJMN 2015-2019 disusun pada tahun 2014, banyak dari target SDGs yang sudah tercakup dalam prioritas pembangunan nasional. Dari sebanyak 169 target yang ada di SDGs, sekitar 57\% (96 target SDGs) telah sesuai dengan prioritas pembangunan nasional. Jika dilihat berdasarkan pilar SDGs, pilar sosial mencakup tujuan nomor 1-5. Dari 47 target, hanya 27 target yang selaras dengan RPJMN. Pilar ekonomi mencakup tujuan nomor 7,8,9,10 dan 17 dalam SDGs. Dari 54 target, sebanyak 30 target telah sejalan dengan prioritas nasional. Pilar lingkungan yang mencangkup tujuan nomor 6, 11, 12, 13, 14, 15 dalam SDGs. Dari 56 target, sebanyak 31 target telah diakomodasi dalam agenda pembangunan nasional. Lalu pada pilar hukum dan tata kelola hanya terdapat satu poin tujuan, yaitu tujuan nomor 16 dalam SDGs. Dari 12 target, sebanyak 8 target SDGs telah sesuai dengan prioritas pembangunan nasional. ${ }^{43}$

\footnotetext{
41 Sekar Panuluh dan Meila Riskia Fitri, "Perkembangan Pelaksanaan Sustainable Development Goals (SDGs) di Indonesia”, dalam https://www.sdg2030indonesia.org/an-component/media/uploadbook/Briefing_paper_No_1_SDGS_-2016-Meila_Sekar.pdf, Akses 7 April 2018, hlm. 11.

42 https://www.bappenas.go.id/id/data-dan-informasi-utama/dokumen-perencanaan-dan-pelaksanaan/ dokumen-rencana-pembangunan-nasional/rpjp-2005-2025/rpjmn-2015-2019/, Akses pada 4 Maret 2019.

43 Ali Said et. al, Potret Awal Tujuan Pembangunan Berkelanjutan (Sustainable Development Goals) di Indonesia, Badan Pusat Statistik, Jakarta, 2016, hlm. 4.
} 
Pasal 1 ayat (2) Perpres No. 59 Tahun 2017 berisi bahwa peta jalan nasional Tujuan Pembangunan Berkelanjutan (TPB) adalah dokumen rencana yang memuat kebijakan strategis tahapan-tahapan dalam pencapaian TPB tahun 2017 hingga tahun 2030 yang sesuai dengan sasaran pembangunan nasional. ${ }^{44}$ Maka dari itu tujuan-tujuan yang terdapat dalam SDGs disesuaikan dengan kondisi di Indonesia melalui RPJMN agar sesuai dengan tujuan yang ingin dicapai baik oleh tujuan secara global yang tertuang dalam SDGs, maupun tujuan pembangunan nasional. Tujuan pembangunan nasional yang dimaksud adalah untuk menjaga peningkatan kesejahteraan ekonomi masyarakat secara berkesinambungan, menjaga keberlanjutan kehidupan sosial masyarakat, menjaga kualitas lingkungan hidup serta pembangunan yang inklusif dan terlaksananya tata kelola yang mampu menjaga peningkatan kualitas kehidupan dari satu generasi ke generasi berikutnya. ${ }^{45}$

Pasal 2 ayat (1) Perpres No. 59 Tahun 2017 yang berisi bahwa Dengan Peraturan Presiden ini ditetapkan sasaran nasional periode tahun 2017 sampai tahun 2019 dalam Rencana Pembangunan Jangka Menengah Nasional 2015-2019, yang selaras dengan TPB sebagaimana tercantum dalam Lampiran dan merupakan bagian tidak terpisahkan dari Peraturan Presiden ini. Sasaran nasional yang dimaksud dalam Pasal 2 tersebut merupakan acuan bagi ormas, filantropi, pelaku usaha, akademisi dan pemangku kepentingan lainnya yang akan menyusun perencanaan, pelaksanaan dan pemantauan serta evaluasi TPB. ${ }^{46}$ Selain itu, pihak-pihak yang mengacu pada sasaran nasional tersebut juga merupakan anggota dari tim pelaksana yang dipimpin dan diketuai oleh Deputi Bidang Kemaritiman dan Sumber Daya Alam Kementerian Perencanaan Pembangunan Nasional/Badan Perencanaan Pembangunan Nasional. ${ }^{47}$

Filantropi memiliki peran yang penting dalam upaya pencapaian TPB/SDGs. Selain hal tersebut, peran filantropi adalah sebagai salah satu sumber pendanaan

44 Pasal 1 ayat (2) Peraturan Presiden No. 59 Tahun 2017 tentang Pelaksanaan Pencapaian Tujuan Pembangunan Berkelanjutan.

45 Pasal 2 ayat (2) Peraturan Presiden No. 59 Tahun 2017 tentang Pelaksanaan Pencapaian Tujuan Pembangunan Berkelanjutan.

46 Pasal 3 huruf b Peraturan Presiden No. 59 Tahun 2017 tentang Pelaksanaan Pencapaian Tujuan Pembangunan Berkelanjutan.

47 Pasal 10 ayat (2) Peraturan Presiden No. 59 Tahun 2017 tentang Pelaksanaan Pencapaian Tujuan Pembangunan Berkelanjutan. 
TPB. Pasal 19 huruf c Perpres No. 59 Tahun 2017 berisi bahwa salah satu sumber pendanaan TPB selain berasal dari $\mathrm{APBN}^{48}$ dan $\mathrm{APBD}^{49}$ juga dapat berasal dari sumber-sumber lain yang sah dan tidak mengikat sesuai dengan ketentuan peraturan perundang-undangan. ${ }^{50}$

Hal ini berarti bahwa dana donasi dan/atau sumbangan yang terkumpul dalam kegiatan filantropi dapat digunakan untuk pendanaan TPB dengan catatan bahwa kegiatan filantropi menjadi kegiatan yang berkelanjutan, tidak hanya bersifat momentum (seperti saat adanya bencana alam, musibah lain atau bantuan sosial). Tentu saja untuk mencapai hal tersebut, diperlukan dasar hukum yang kuat sebagai payung bagi filantropi untuk menjalankan kegiatannya agar dapat berkelanjutan sehingga menjadi salah satu sumber dana potensial bagi pencapaian TPB 2030.

Agar hukum dapat tanggap dengan perubahan-perubahan yang ada dalam masyarakat dalam rangka mendukung pembangunan yang berkelanjutan, maka hukum harus memiliki sifat responsif. Hukum responsif melihat hukum sebagai fasilitator (sarana) dari respon terhadap kebutuhan-kebutuhan sosial dan aspirasiaspirasi sosial. ${ }^{51}$ Hukum harus selalu dikaitkan dengan tujuan-tujuan di luar narasi tekstual hukum itu sendiri, hal ini disebut dengan "The Souvereignty of Purpose". 52

"Thus a distinctive feature of responsive law is the search of implicit values in rules and policies.... a more 'flexible' interpretation that sees rules as bound to specific problem and contexts, and undertakes to identify the values at stake in procedural protection".

Hukum responsif pada akhirnya yang dipermasalahkan adalah tujuan tata tertib sosial. Hukum responsif berasal dari suatu hasrat untuk membuat hukum lebih bertujuan di dalam melayani manusia dan institusi-institusi untuk mencapai tidak hanya keadilan yang formal, tapi juga keadilan yang substantif. Hukum

\footnotetext{
48 Pasal 19 huruf a Peraturan Presiden No. 59 Tahun 2017 tentang Pelaksanaan Pencapaian Tujuan Pembangunan Berkelanjutan.

49 Pasal 19 huruf b Peraturan Presiden No. 59 Tahun 2017 tentang Pelaksanaan Pencapaian Tujuan Pembangunan Berkelanjutan.

50 Pasal 19 huruf c Peraturan Presiden No. 59 Tahun 2017 tentang Pelaksanaan Pencapaian Tujuan Pembangunan Berkelanjutan.

51 Siti Malikhatun Badriyah, Sistem Penemuan Hukum dalam Masyarakat Prismatik, Cetakan Pertama Sinar Grafika, Jakarta, 2016, hlm 53.

52 Satjipto Rahardjo, Hukum Progresif: Sebuah Sintesa Hukum Indonesia, Cetakan Pertama, Genta Publishing, Yogyakarta, 2009, hlm 6-7.
} 
responsif yang dicita-citakan menuntut pada suatu penafsiran yang lebih fleksibel yang melihat aturan sebagai hal yang terikat pada suatu masalah dan konteks yang khusus, dan mencoba untuk mengidentifikasi nilai-nilai yang dipertaruhkan dalam perlindungan prosedural. Jika nilai-nilai ini diperjelas maka akan memberikan kriteria yang otoritatif (memaksa) untuk mengkritik aturan-aturan yang ada dan membentuk aturan-aturan baru. Hukum tidak dilihat sebagai hukum itu sendiri, melainkan apa yang sebenarnya dapat disumbangkan oleh hukum untuk kepantasan dalam masalah-masalah sosial dan untuk keadilan sosial yang substantif. ${ }^{53}$

Hukum yang bersifat responsif dapat menangkap makna dari urgensi pembaruan dasar hukum dalam kegiatan filantropi di Indonesia, yaitu UU No. 9 Tahun 1961 tentang Pengumpulan Uang atau Barang. Selain itu juga karena undang-undang merupakan cara pengaturan hukum yang utama. Pembaruan masyarakat dengan jalan hukum berarti pembaruan hukum terutama melalui undang-undang. ${ }^{54}$ Perubahan-perubahan yang salah satunya diakibatkan oleh pembangunan, harus ditanggapi dengan cepat. Reaksi yang cepat tanggap ini dimaksudkan agar pembaruan subtansial dasar hukum tersebut dapat menjamin keadilan para pihak yang terlibat dalam kegiatan filantropi di Indonesia. Apabila filantropi sudah memiliki dasar hukum (undang-undang) yang responsif dan dapat menjamin kepastian dan keadilan hukum kegiatan filantropi di Indonesia, maka filantropi dapat menjadi salah satu unsur penting dalam pembangunan Indonesia sesuai dengan agenda SDGs 2030.

\section{Penutup}

Pembaruan Undang-undang No. 9 Tahun 1961 tentang Pengumpulan Uang atau Barang dalam kegiatan filantropi di Indonesia tidak bisa dilihat sebagai hukum dari sudut pandang yang bersifat positivistik yang beranggapan bahwa hukum harus bebas nilai dan tertutup. Pembaruan menuntut adanya perubahan yang dalam prosesnya terdapat banyak faktor lain di luar hukum yang memegang

53 Siti Malikhatun Badriyah, Sistem Penemuan Hukum..., Op. Cit., hlm. 54.

54 Mochtar Kusumaatmadja, Konsep-Konsep Hukum dalam Pembangunan, Cetakan Kedua, PT Alumni, Bandung, 2006, hlm. 89. 
peranan penting, seperti faktor sosial dan ekonomi. Hal tersebut membuat pembaruan undang-undang penuh dengan nilai-nilai lain di luar hukum.

Upaya pembaruan UU No. 9 Tahun 1961 dalam kegiatan filantropi di Indonesia agar dapat menunjang pencapaian SDGs 2030 dapat dilakukan dengan merevisi ketentuan yang mencakup: (a) Pengumpulan dana sumbangan berbasis internet/teknologi informasi; (b) Pengelolaan dana sumbangan untuk keperluan operasionalisasi kegiatan pengumpulan dana; (c) Pemisahan rekening dana sumbangan; (d) Pengaturan penerimaan donasi melalui media elektronik; (e) Mekanisme pelaporan penyelenggaraan dan hasil sumbangan; (f) Pembedaan dana filantropi dengan dana CSR; (g) Bentuk badan usaha; (h) Penerapan Sanksi; (i) Pengaturan penggalangan dana sumbangan melalui retail modern.

Selain itu, juga perlu mengonfigurasi tujuan-tujuan yang ada dalam SDGs menjadi kebijakan pembangunan nasional. Hal ini dikarenakan masih terdapat $43 \%$ tujuan SDGs belum sesuai dengan prioritas pembangunan nasional. Salah satu hal yang dapat mengoptimalkan pencapaian tujuan-tujuan tersebut adalah pelibatan secara aktif lembaga filantropi di Indonesia, yang dalam hal ini terkait dengan sumber dana yang perlu digunakan untuk mencapai pembangunan yang berkelanjutan.

\section{Daftar Pustaka}

\section{Buku}

Badriyah, Siti Malikhatun. Sistem Penemuan Hukum dalam Masyarakat Prismatik. Cetakan Pertama, Sinar Grafika, Jakarta, 2016.

Darmodiharjo, Darji. Pokok-pokok Filsafat Hukum: Apa dan Bagaimana Filsafat Hukum Indonesia, PT Gramedia Pustaka Utama, Jakarta, 1995.

Kusumaatmadja, Mochtar. Konsep-konsep Hukum dalam Pembangunan, Cetakan Kedua, PT Alumni, Bandung, 2006.

Manan, Abdul. Peranan Hukum dalam Pembangunan Ekonomi. Cetakan Pertama, Prenadamedia Group, Jakarta, 2014.

Rahardjo, Satjipto. Hukum Progresif: Sebuah Sintesa Hukum Indonesia, Cetakan Pertama, Genta Publishing, Yogyakarta, 2009.

Said, Ali et. al. Potret Awal Tujuan Pembangunan Berkelanjutan (Sustainable Development Goals) di Indonesia, Badan Pusat Statistik, Jakarta, 2016. 
Samekto, FX. Adji. Studi Hukum Kritis: Kritik Terhadap Hukum Modern, PT Citra Aditya Bakti, Bandung, 2005.

\section{Jurnal}

---------, "Peran Filantropi dalam Pengentasan Kemiskinan di dalam Komunitas Lokal". Jurnal Sosiologi Islam, Edisi No. 1 Vol. 1, April, 2011.

Ahmadi, Makhrus. "Pengembangan Dana Zakat, Infak, Shadaqah dan Wakaf terhadap Pertumbuhan Industri Keuangan Non Bank Syariah". Jurnal Masharif al-Syariah, Edisi No. 2 Vol. 2, 2017.

Bhawika, Gita Widi. "Risiko Dehumanisasi pada Crowdfunding sebagai Akses Pendanaan Berbasis Teknologi di Indonesia". Jurnal Sosio Humaniora. Edisi No. 1 Vol. 10, Juni 2017.

Draft Naskah Akademik Rancangan Undang-undang tentang Penyelenggaraan Sumbangan, Biro Hukum, Kementerian Sosial Republik Indonesia, 2017.

Hariyani, Iswi dan Cita Yustisia Serfiyani. "Perlindungan Hukum Sistem Donation Based Crowdfunding pada Pendanaan Industri Kreatif di Indonesia". Jurnal Legislasi Indonesia. Edisi No. 4 Vol. 12, Desember 2015.

Irfan, Maulana. "Crowdfunding Sebagai Pemaknaan Energi Gotong Royong Terbarukan". Social Work Jurnal. Edisi No. 1 Vol. 6, 2016.

Putra, Marsudi Dedi. "Kontribusi Aliran Sociological Jurisprudence Terhadap Pembangunan Sistem Hukum Indonesia". Likhitaprajna. Edisi No. 2 Vol. 16, 2014.

Ramadhan, Choky R. "Konvergensi Civil Law dan Common Law di Indonesia dalam Penemuan dan Pembentukan Hukum". Mimbar Hukum, Edisi No. 2 Vol. 30, Juni 2018.

Suliantoro, B. Wibowo. "Dinamika Arah Kepastian Hukum di Tengah Transformasi Sosial-Budaya dalam Perspektif Pemikiran Mazhab Sociological Jurisprudence". Jurnal Filsafat. Edisi No. 1 Vol. 17, 2007.

Tamim, Imron Hadi. "Filantropi dan Pembangunan. Community Development", Edisi No. 1 Vol. 1, Juni, 2016.

Widagdo, Singgih. “Analisis Yuridis terhadap Undang-undang No. 4 Tahun 2009 tentang Pertambangan Mineral dan Batubara dari Aspek Hukum Bisnis". Tesis, Program Magister Hukum, Universitas Gadjah Mada, Yogyakarta, 2011.

\section{Internet}

Sekar Panuluh dan Meila Riskia Fitri, "Perkembangan Pelaksanaan Sustainable Development Goals (SDGs) di Indonesia", dalam https://www.sdg2030indonesia.org/an-component/media/uploadbook/Briefing_paper_No_1_SDGS_-2016-Meila_Sekar.pdf, Akses 7 April 2018. 
http:/ / majalahcsr.id/ruu-pub-untuk-kepercayaan-pada-lembaga-filantropi/, Akses pada 28 Mei 2018.

http:/ / filantropi.or.id/keanggotaan, Akses pada 3 Februari 2019.

https://www.bappenas.go.id/id/data-dan-informasi-utama/dokumenperencanaan-dan-pelaksanaan/dokumen-rencana-pembangunannasional/rpjp-2005-2025/rpjmn-2015-2019/, Akses pada 4 Maret 2019.

\section{Peraturan Perundang-undangan}

Undang-Undang Dasar Negara Republik Indonesia Tahun 1945.

Undang-undang No. 9 Tahun 1961 tentang Pengumpulan Uang atau Barang.

Undang-undang No. 32 Tahun 2002 tentang Penyiaran.

Peraturan Pemerintah No. 29 Tahun 1980 tentang Pelaksanaan Pengumpulan Sumbangan.

Peraturan Pemerintah No.22 Tahun 2008 tentang Pendanaan dan Pengelolaan Bantuan Bencana.

Peraturan Presiden No.59 Tahun 2017 tentang Pelaksanaan Pencapaian Tujuan Pembangungan Berkelanjutan.

Peraturan Komisi Penyiaran Indonesia tentang Pedoman Perilaku Penyiaran. 